\title{
Building Strategic Competency for Six-Sigma Implementation: A Model for Saudi Arabia
}

\author{
Ziaul Huq \\ University of Nebraska at Omaha \\ Hamid Alalwany \\ Umm Al-Qura University \\ Majid Almaraashi \\ University of Jeddah
}

Ever since Saudi Arabia became a member of the World Trade Organization (WTO) in 2002, Saudi companies had to take quality seriously because of increased international competition. In recent years six-sigma approach is being gradually adopted in some companies to improve quality and competitiveness. In this paper we develop a model that addresses the organizational and workforce competency of the six-sigma adopters in Saudi Arabia and provide a roadmap for its successful adoption. Our qualitative study reveals that leadership support for strategy and sustainable promotion of six-sigma implementation in Saudi Arabia is lacking, expatriate quality professionals have to convince management about any six-sigma project they want to initiate. From design perspective management needs to focus on SIPOC, training programs, reward system, internal marketing, and building the IT infrastructure for sixsigma. However, there are many positives in support six-sigma in Saudi Arabia, such as, Saudi government's Vision 2030 for general economic development, availability of trained expatriate quality professionals, Saudi managements proclivity for immediate results which is a hallmark of six-sigma, strong national IT infrastructure, just to name a few. The paper concludes with a prescription on building competency for six-sigma in Saudi Arabia.

Keywords: Six-sigma, competency, Saudi Arabia

\section{INTRODUCTION}

The world of business and management has changed dramatically over the years, especially in the last two decades. Markets have become global, to compete in this global marketplace companies in developed as well as in developing economies must focus on quality management practices. Saudi Arabia is at the crossroads of such a transition. With the announcement of Vision 2030 by the Saudi Government to rejuvenate the private sector for economic development of the country vis-à-vis reduce the country's dependence on oil revenue, adoption of world class business practices such as six-sigma will become 
important for Saudi Arabia for the public sector to compete in a global marketplace. Six-sigma quality program has been successfully applied to varieties of business settings, environmental protection, supply chain management in business and defense services, and operations decision making in government agencies. Anecdotal evidence through case studies reported in literature suggests that six-sigma quality program requires certain competencies for its successful implementation. Recent publications (EscrigTena \& Bou-Llusar, 2005; Huq, 2017; Huq, 2006) offer the argument that without certain required competencies six-sigma implementation will fail. This paper aims at providing a framework of competency requirements from strategic point of view for six-sigma implementation in a developing economy setting for a country like Saudi Arabia. This will be helpful for companies and organizations in the developing countries by providing them with a roadmap for six-sigma implementation. As adoption of six-sigma quality program continues to gain momentum globally, this research will not only close a vacuum in the current six-sigma literature, it will enable companies to make an assessment of their sixsigma readiness.

In order to successfully implement a six sigma program one needs to have certain competencies (Huq, 2006, 2017; Jones, Parast, \& Adams, 2010; Linderman, Schroeder, Zaheer, \& Choo, 2003; Moosa \& Ali, 2010). The needed competencies can be viewed from two different perspectives, namely: (i) as assets, skills, or resources belonging to the company/organization that allow an activity to be performed systematically, and (ii) firm's ability to integrate the assets and orchestrate a cohesive implementation of the program. The first one relates to strategic issues such as workforce competency, quality culture, and employee motivation and the second one involves leadership at various levels of six-sigma implementation. Cohen and Levinthal (1990), Easton \& Rosenzweig (2012), and Formby and Dave (2016) state that a firm's stock of prior knowledge determines the ability of a firm to absorb new knowledge and apply it successfully, for six sigma it means abilities and specific skills that the firm possesses in the deployment of its resources, as well as its cognitive characteristics, which are geared toward the accomplishment of six-sigma results. Although empirical research on determination of competency resources -- as to how they are formed or acquired -- remains rare (Pfeifer, Reissinger, \& Canales, 2004; Williamson, 1999) case studies have shown that companies with established quality systems can easily integrate six-sigma because they fulfill the prerequisites for six-sigma (Pande \& Neuman, 2000). However, many companies adopt six-sigma without knowing about the competencies needed for its implementation, our objective in this paper is to help those companies so that they can make an informed decision about its adoption.

\section{METHODOLOGY}

This is a qualitative study of the competencies needed, or the lack thereof, to adopt six-sigma in the backdrop of strategic strengths and weaknesses prevailing in the public sector of Saudi Arabia. The authors have interviewed a number of CEO's, quality managers, entrepreneurs in the Saudi private sector that includes food industries, consumer goods, energy, pharmaceuticals and health care, and small manufacturers. The paper focuses on strategic decisions needed for six-sigma implementation. The paper is a qualitative study based on discussions with CEO's, company executives, and quality professionals engaged in six-sigma and other quality programs in both manufacturing and service companies. The use of qualitative research techniques is appropriate for gaining information inductively in such behavioral studies. This approach gives company officials an opportunity to respond openly to inquiries about their experiences in implementing six-sigma. A qualitative study can be a valid scientific enquiry if it fulfils the criteria of reliability, validity, and generalizability (Azham \& Hamidah, 2011). The inquiries, posed by the researchers, came from constructs presented in the literature on six-sigma strategic competency dimensions, the content validity of these six sigma constructs (Figure 1) is determined by published literature (Antony \& Banuelas, 2001; Coronado \& Antony, 2002; Gabor, 2001; Huq, 1995, 2006, 2017; Huq \& Martin 2001, Jones et al., 2010; Motwani, Kumar, \& Antony, 2004; Schroeder, Linderman, \& Choo, 2006; Shah, Chandrasekaran, \& Linderman, 2008; ; Pande \& Neuman, 2000). 
Reliability, on the other hand, relates to measurements that can be independently verified has no relevance in qualitative research (Golafshani, 2003; Stenbacka, 2001;). Golafshani (2003) states that to ensure reliability in qualitative research, examination of trustworthiness is crucial. The trustworthiness of this study is corroborated by other studies on quality management in Saudi Arabia (Asamadi, Lehaney, \& Khan, 2012; Muhareb \& Graham-Jones, 2014). An open ended discussion format was used to interview the respondents, Table 2 and 3 represent the strategic organizational and workforce competency identifiers for six-sigma adoption. The word generalizability is usually defined as the degree to which the results of a study based on a sample can be applied to an entire population, and qualitative studies have generally found it difficult to satisfy this criterion. However, there are other positive aspects of qualitative studies that can satisfy generalizability within a specific situation or case, Lewis and Ritchie (2003) calls it representational generalizability. Our study satisfies this condition based on the evidence from other studies on quality in Saudi Arabia (Asamadi et al., 2012; Muhareb \& Graham-Jones, 2014).

\section{FIGURE 1}

\section{STRATEGIC COMPETENCY DIMENSIONS}
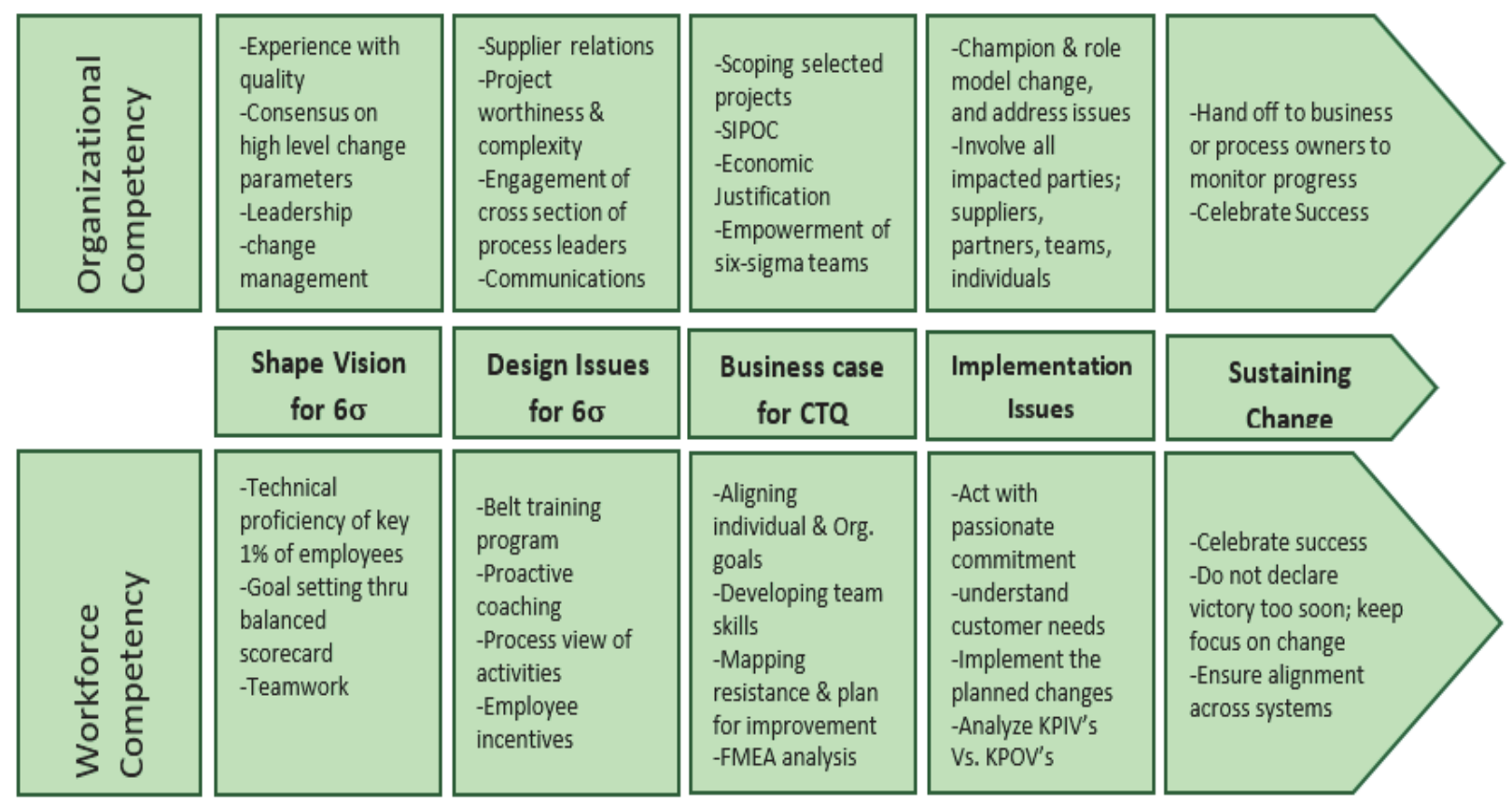

\section{Why Six-sigma Should Appeal to Saudi Management}

Since Saudi Arabia joined the World Trade Organization (WTO) in 2002, the Saudi market became part of the global market. Membership in the WTO resulted in reduction of import tariff from 13 percent to 5 percent, local Saudi firms started facing international competition thus focusing on quality became imperative. Over the last two decades manufacturing and service companies in Saudi Arabia have tried to implement Total quality management (TQM), Kaizen, ISO certification, Business Process Reengineering (BPR), Lean, etc., with limited success (Asamadi et al., 2012; Muhareb \& Graham-Jones, 2014). Many of these implementations could not fulfil the inherent optimism of management in these companies that there is a quick fix to their quality problems notwithstanding the fact that benefits of most of these approaches are realized years after their adoption. Now, enter six-sigma, immediate benefits of six-sigma are well known (Pande \& Neuman, 2000) if it is implemented in an appropriate environment. One of the features of six-sigma is that it is results oriented, and the economic justification used in project selection highlights the immediate benefits to the company implementing the project. This feature of six-sigma lures many to adopt it without considering the fact that the company may not have the competency to implement it, and 
companies in Saudi Arabia are not immune from that trap. Observing the success of Six Sigma quality program at Motorola (reported a cumulative savings of $\$ 17$ billion till 2006), GE (reported \$ 2 billion savings in 1999 alone), Allied Signal, Citigroup, and Sony (Pande \& Neuman, 2000) many have launched the six sigma quality improvement program in their companies, literature (Asamadi et al., 2012; Muhareb \& Graham-Jones, 2014) suggests that many companies in Saudi Arabia are attempting to do the same. Asamadi et al. (2012) reports out of one hundred top manufacturing and service companies in Saudi Arabia about 32 percent are attempting six-sigma, and their adoption is best described as half-baked implementations.

Most businesses in Saudi Arabia are family owned (Najeh \& Kara-Zaitri, 2007), decision making processes in such businesses are rigidly top down, participative management or horizontal organizations are not part of the management culture of Saudi Arabia. The good thing about six-sigma is that Top management in Saudi Arabia should love it because it is more focused on technology, measurements, and results as opposed to culture and people building approach taken by other quality management techniques. Although six-sigma also focuses on building workforce culture, but that culture is not a pervasive culture, it does not require conformance by the entire workforce, rather it is rooted in process innovation through careful study by an elite sub-group. It should appeal to Saudi business leaders because it is a top-down approach that involves only technically savvy process leaders in the company who can be given a clear charter and be held accountable to fulfil that charter. From management point of view it is an easier control mechanism than holding everyone responsible. Unlike other quality approaches, i. e., TQM, etc., six-sigma does not try to improve everything simultaneously, selected projects need to target only few key processes and few selected employees. In case of failure, management can easily drop the project - without widespread damage-and move on to more profitable projects. Another advantage of sixsigma over other quality management practices lies in its limited training requirements, six-sigma does not require training for all employees in the company, it needs to train only 1-5 percent of the employees in six-sigma concepts. Although the training for black belts and green belts in six-sigma is more rigorous than training requirements for other quality approaches, deployment of six-sigma is more rapid because only few people need to be trained. For Saudi Arabia it is particularly important because a major part of the technocrats who work here are expatriate workers who can be given a clear charter and held accountable for project success. Companies planning six-sigma adoption can initially hire technically savvy and six-sigma trained expatriate workers to launch the program and eventually build local expertise through the expatriate workers. With the governments focus on improving the private sector in its Vision 2030 plan, there will be new impetus to adopt the best-of-breed management practices in the private sector. To implement six-sigma, privately held companies will most likely prefer expatriate technocrat workers, which would be consistent with the management culture in Saudi Arabia. As opposed to many industrialized nations labor management does not pose to be a challenging issue in Saudi Arabia as there is no union and the bargaining process is biased in favor management because of the contractual agreement with the expatriate workers (Najeh \& Kara-Zaitri, 2007).

One thing became clear to the authors of this article at the very outset, the six-sigma toolset is well known to most of the interviewed companies, many are using them on a selective basis, however, they are not calling that adoption six-sigma yet. Many of the technically savvy quality people are expatriate workers, and their knowledge and expertise has just started to trickle down to their Saudi counterparts. Another advantage of six-sigma that may appear consistent with Saudi management culture is its management by exception principle. Family owned businesses are not generally interested in taking a long term view of the well-being of the company, they have a myopic view of company operations outcome-how much money we are going to make this quarter. The economic justification used in selecting six-sigma projects can show management the immediate benefits to the company. As the quality system is based on technology, mechanization, and specialization as opposed to humanization of the system-an approach consistent with Taylor's scientific management-it is supposed to appeal to Saudi management because of their inclination for top down decision making processes. Of course, the biggest appeal of six-sigma to Saudi management would be is its focus on attacking quality problems-one at a time, based on customer mandated CTQ's (critical-to-quality) that are more manageable and easier to 
fulfil than attempting to improve everything simultaneously. Also, the goal setting process of six-sigma will be consistent with Saudi management approach that not only implements customer mandated CTQ's, but also verifies each proposed project (CTQ) against the corporate strategy, economic justification, and company's competitive capability.

As TQM became unattractive in the western industrial world, new terms for excellence in quality such as Business Excellence, Organizational excellence, six-sigma, or lean six-sigma appeared on the horizon. For Saudi Arabia, Asamadi et al. (2012) reports that Saudi enterprises also got disillusioned with ISO certification, business process re-engineering (BPR), total quality management (TQM) and Kaizen because the benefits of some of these approaches are not quality focused, and some require long term commitment. Special mention goes to ISO Certification and business process re-engineering; ISO Certification does not guarantee quality because it is a certification that states the certified company has a documented quality system in place and supposedly they are using it, the key lies in their using it. BPR on the other-hand is focused on streamlining of operations by reducing transactions and removal of nonvalue added activities for better customer service and profits. Both are pervasive operations systems that require discipline in implementing them. The advantage of six-sigma is that it not a pervasive system, it can be tailored to the extent of the company's competitive capability. Multiple six-sigma projects can be implemented simultaneously that may involve a small section of the company, a certain process or department, or even a nested sub-process. Six-sigma has common themes with TQM but is structurally different. Dahlgaard-Park (2011) categorizes it as more mechanistic and rational in its approach that invites only competent people in the organization to get involved. It is a big convenience of six-sigma in terms of participatory management that management does not need to get involved with the entire workforce. Its deployment can be rapid because only a small section of the workforce needs to get sixsigma trained.

\section{Some Preliminary Requirements for Six-sigma}

Six-sigma requires both organizational and workforce competency, literature has shown that the successful adopters of six-sigma had years of experience with quality programs (Antony \& Banuelas, 2001; Gabor, 2001; Motwani et al., 2004). Recent articles by Formby and Dave (2016) and Gutierrez, Bustinza, and Barreles (2012) indicate maturity of the organization and absorptive capacity of the workforce plays a vital role in six-sigma implementation. Based on their research Formby and Dave states, "organizational experience, generally greater than 5 years, and the breadth and depth of workforce involvement, generally greater than $10 \%$, are significantly related to successful implementation of six sigma improvements." They comment that effectiveness in implementing six sigma improvements appears to continue to improve with experience and time, and involvement of workers between 5-10 percent of the workforce may contribute to gradual success in six-sigma implementation. Gutierrez et al. (2012) show that six sigma teamwork and process management positively affect the development and absorptive capacity of the workforce that lead to an organizational learning orientation. Both of these studies, i.e. Formby and Dave (2016) and Gutierrez et al. (2012), indicate that the successful six sigma adoption process is gradual. For Saudi companies, even though they may not have the ideal situation in terms of organizational and workforce competency, with experience in TQM they can start six-sigma on a small scale. With passage of time the organization will gradually mature and organizational learning will take root.

Six-sigma is a non-intuitive data driven methodology, therefore company experience with quality programs is essential. Naser (2007) and Alotaibi (2013) found that quality culture do exist in many Saudi companies, especially in the food industry, that were forced to adopt TQM practices to counter international competition after Saudi Arabia became a member of the WTO in 2005. Study by Alotaibi (2013) confirmed that there is significant relationships between all total quality management practices and quality culture in Saudi Arabia, and a positive relationship exists between quality management practices and quality culture. The study found the evidence that quality culture can be improved with structured training and dissemination of quality management practices. These two studies focused on dissemination of TQM practices that require a pervasive quality culture where everyone must be trained in quality 
management practices. Six-sigma, however, does not require a pervasive quality culture and not everyone in the company needs to be trained. Although the training for six-sigma is more rigorous than the training for TQM, six-sigma requires only 1-5 percent of employees, i. e., the technically savvy employees, need to be trained. Therefore, the deployment is more rapid, and it has the advantage of starting the program on a pilot scale and gradually replicate it throughout the company. Our findings reveal that most Saudi companies do not have a dominant quality culture comparable to successful six-sigma implementers such as Motorola, GE, Allied Signal, or Citibank. However, competitive pressure has obligated many companies to adopt TQM and disseminate the method throughout their companies, some are using that training to implement six-sigma type projects although many are not calling that six-sigma. These marginal six-sigma implementers select projects on an ad hoc basis, there is no structured leadership for cohesive implementation of the projects, and often there is no concerted effort to select projects based on economic justification. Many of these ad hoc projects are led by expatriate quality professionals-on rare cases by a Saudi six-sigma trained professional-who are six-sigma belt trained and were hired to oversee quality implementation. Top management is not usually involved in directing these projects, and the quality professionals have to convince the top management about the positive outcome of such projects for approval. If the quality professionals can demonstrate the immediate benefits of such projects, it is easy to get approval. This myopic view of the leadership is one of the structural problems in most management hierarchies of Saudi Arabia, they are not convinced if the benefits of a quality improvement project are years away after implementation. In addition, family ownership of most companies precludes shared governance, or a structure that provides the employees flexibility and independence.

From a strategic point of view management in Saudi Arabia needs to create an environment of participation with a compelling company mission that motivates and rewards the elite among the workforce to get involved and participate. To initiate the program creation of a task force comprising of company leadership, process leaders, partners, and suppliers is the first step. This team will assess the compatibility of six-sigma with company goals and objectives, need for changes in the way things are done, barriers to implementation, and preparedness of the company in implementing the quality program. Before any decision is made, an assessment of the competitive capability, readiness of the workforce and their training needs, and the type of participatory management needed for six-sigma needs to be addressed. Companies often decide on their competitive priorities without assessing their competitive capabilities, for six sigma it implies management's experience with other quality systems and large-scale change initiatives, and the ability of the workforce to absorb new knowledge and adapt to the new mission. Works by Muhareb and Graham-Jones (2014) and Asamadi et al. (2012), and our own findings indicate that companies are leveraging their past experience in TQM to initiate implementation of sixsigma. The principle investigator of this research was part of a six-sigma training initiative in Saudi Arabia, and there are other accredited consulting companies-both national and international-that are involved in offering six-sigma belt training programs. In addition, most companies focused on quality have hired belt trained quality professionals from abroad, these expatriate professionals are helping in developing the local cadre of quality specialists. Out of the ten companies we have surveyed, all encourage their employees in the quality department to obtain certification and offer time off from work to attend training classes. Almost seventy percent of quality professionals in the surveyed companies are expatriate workers, they offer proactive coaching to their local subordinates to improve quality and process performance. Without the required training six-sigma will not be possible, not only for creating a technically savvy class of professionals, but also for creating a structured leadership configuration. This structured leadership creates a quality culture where it is easier to focus more on the process elements (process innovation, process management, workforce management, supplier relationship, design function, training, statistical analysis of process data, the measurement system analysis) than other techniques (Coronado \& Antony; 2002; Motwani et al., 2004; Schroeder et al., 2008). One of the important requirements for successful implementation of six-sigma is that the project teams not only develop a deep understanding of the process, they must be passionate about improving the process because it may require breakthrough rates of improvement and innovation. The process leaders play a vital role in molding the behavior and commitment of the process members. Management must provide the empowerment, 
direction, and guidance to these process leaders, it must adopt a cooperative orientation towards power sharing. From a participative management perspective, it would be easier for Saudi management to focus on coalition building with few quality professionals, i. e. process leaders, than work with a multitude of employees where they may have to deal with more resistance and interdepartmental turf battles. There still may be employee resistance, internal marketing has been suggested to ameliorate the situation (Davis, 2001). The good thing about six-sigma is that internal marketing is focused towards this elite group, something that may not require too much resources. This is management by exception- where everything is done keeping the company bottom line in proper perspective-an approach that should be more palatable to Saudi management cultural practices.

Projects are the means by which six-sigma reduces costs of quality and improves better customer service and financial performance. Each project represents a critical quality dimension of a product or service referred to as CTQ (critical-to-quality), selected after careful evaluation of customer inputs, economic justification, and company strategic goals and objectives. Project prioritization based on economic justification is a significant part of six sigma that was not part of other quality management practices. Banuelas and Antony (2002) and Pande (2000) discuss the project assessment and prioritization approaches used by practitioners, among them techniques such as cost benefit analysis, cause and effect matrix, brainstorming, Pareto analysis are noteworthy. Project selection can be centralized or decentralized (De Mast, 2007), in a decentralized setup process teams are empowered to select projects with approval from the six-sigma champion. However, it is recommended that in order to cascade down the company goals and priorities to the project level the executive suite must get involved for final approval of projects. This is where Saudi management needs to make some changes, according to our survey of quality professionals ninety five percent of them said that all decision making is centralized, sometimes top management do not even listen to any professional advice. This top down approach can become the biggest bottleneck for successful implementation of six sigma, top management needs to listen to the advice of trained professionals, empower them to use their training and experience in proposing projects that are most beneficial to the company bottom line. There has to be a cooperative orientation in selecting six sigma projects. From six sigma perspective it is proper to use a top down approach to set the overall goals, and use a bottom up approach to achieve the goals through the selection of appropriate projects. To create an environment where employees take initiatives to innovate better ways to accomplish the project goals, management must continuously reinforce its support of the employees, empower them, and drive away the fear of taking risks. For this an effective communications strategy is needed, it should not be limited to just web postings, emails, or through a single point of contact; the executive suite must hold gatherings, question and answer sessions with the six sigma professionals to fortify a sense of trust and cooperation.

\section{The Competency Model}

In this paper we present a model of strategic preparedness for launching six-sigma. The model covers the organizational competencies and workforce competencies needed for six sigma implementation in the country. For cohesive implementation six sigma must be an integral part of the company strategic plan that will help guide project selection and execution. Six sigma champion should be part of the corporate strategic planning committee to guide the executive suite to design for six sigma. We need to understand that the success of six sigma at Motorola and GE was predicated on acceptance of six sigma as a strategic initiative (Pande \& Neuman, 2000). Corporate leadership plays a vital role in its success (Davison \& AlShaghana, 2007; Jayaraman, Kee, \& Soh, 2012). Executive suite has to take an active role in creating the task forces and deployment of the six sigma initiative, and for maintaining the momentum of the change effort. It needs to create the leadership structure where top managers work as change agents throughout the organization to select series of process improvement projects that result in improved performance on measures of vital importance to the company and its customers. Senior managers must also guide the creation, training, and support the lower strata of six sigma professionals who will become members of

project teams. The executive suite needs to create a sense of participative management within the six sigma group of professionals, provide them with a compelling mission to act upon, and empower them to 
try new methods and procedures to improve process performance. The executive suite also needs to understand that their actions play a vital role in molding employee behavior towards six-sigma goals and objectives.

For Saudi Arabia six sigma is not a radical re-thinking approach, as mentioned earlier, many companies are using the six sigma toolset but yet they are not calling it six sigma. Some companies after getting disillusioned with TQM are not ready to jump in the bandwagon to implement six sigma, but the training from TQM enables them to apply six sigma principles selectively. However, without strategic commitment the benefits of six sigma will be hard to achieve. We need to understand that six-sigma is focused on process innovation through meticulous attention to details, understanding the relationships between Key Process Input Variables (KPIV) and Key Process Output Variables (KPOV) through advanced statistical analyses, without any regard for the opinion of the people who implement it.

Figure 1 represents the strategic dimensions of competency for implementing six sigma, the model is discussed in Huq (2017) published in American Management Journal (AMJ). At the strategic level a company needs competency both at the organizational and workforce levels. Six-sigma is not a radical rethinking approach, however, it becomes one if the company has no prior experience with quality management practices. Six-sigma is fixated on meticulous attention to details, application of advanced statistical tools, and mechanistic without regard to needs, desires, and fears of the employees who implement it, such a transition requires change management. Since six-sigma is a data driven nonintuitive approach, it requires a technically proficient workforce, at least the process leaders must be technically proficient. Deming said without statistical evidence quality cannot be improved. One needs technical expertise to apply SPC and to study process capability, six-sigma requires that. Goals should be set keeping in view fulfillment of the company strategic goals and customer supplied CTQ's, and team work is the foundation of that. Goal setting, i. e., selection of six-sigma projects through economic justification, can be centralized, decentralized, or integrated, it works best when the process is integrated. It also requires workforce competency.

Design issues for six-sigma are part of the strategic aspects of competency. At the design stage one needs to address supplier selection policies, project worthiness vis-à-vis company strategic goals, communications, employee training programs, and incentive programs for employees. Suppliers processes should also have competency, poor supply quality means bad quality. Supplier's process capability must be certified. Complexity of the project will determine the level of engagement by sixsigma staff, suppliers, partners, and customers. Training is an essential part of six-sigma, however, it should not stop at that; successful companies go one step further, they use proactive coaching beyond the belt training. Process employees (usually green belts) are coached by a black belt about the process attributes, Key Process Input Variables (KPIV) and Key Process Output Variables (KPOV).

Making the business case for each six-sigma project is a prerequisite for six-sigma program. Scope of each six-sigma project should be studied, projects that benefit other related processes should get priority, each project represents a CTQ, selected based on customer preferences, company strategic objectives, and economic benefits to the company. To have a better grasp of the process linkages one needs to study the entire supply chain, a SIPOC map (supply-input-process-output-customer) or a value-stream map can be very useful at this stage. The importance of the supply chain can hardly be overemphasized because the efficiency and effectiveness of the process performance is entirely dependent on its supply chain, especially when major components of the product or service are procured externally. When employees identify company goals as their own goals, participation increases and resistance diminishes. Company should have contingency plan in place if a six-sigma project fails.

The implementation issues at the strategic level involves maintaining a process view, customer focusit may be an internal customer, creating the passion for six-sigma among the involved workforce, and understanding the causal relationship between key process input variables (KPIV) and key process output variables (KPIV). In a six-sigma project roles of process owners will change, and all project employees, suppliers, and partners must get involved. Finally, sustaining change and celebrating success is an important hallmark of any change program, they contribute to employee commitment. Six sigma staff must understand the relationships between KPIV's and KPOV's, how to measure them and creation of 
systems and procedures that are simple, user-friendly, and fool proof. This is where six-sigma diverges from other quality programs, at this point we justify the appropriateness of selecting a six-sigma project through economic justification and strategic goals of the company.

\section{Testing the Competency Model in Saudi Arabia}

To test our model we selected ten groups of quality professional who work in various manufacturing and service companies in Saudi Arabia. These groups of professionals were interviewed by the principle investigator over a period of three months. We operationalized the six sigma strategic organizational and workforce competency dimensions into practical identifiers of competency for six sigma success. Questions posed to the quality professionals were based on these identifiers, they were asked to assess the state-of- affairs in their companies against these identifiers. It was interesting to note that seventy percent of these quality professionals were expatriate workers, and forty percent of them were six sigma belt trained. The organizational and the workforce competency identifiers along with the responses of the Saudi professionals are presented in Tables 2 and 3.

\section{TABLE 2}

\section{ORGANIZATIONAL COMPETENCY DIMENSIONS AND IDENTIFIERS}

\begin{tabular}{|c|c|c|}
\hline $\begin{array}{c}\text { Strategic } \\
\text { Dimensions }\end{array}$ & $\begin{array}{c}\text { Ideal Organizational Competency } \\
\text { Identifiers } \\
\end{array}$ & $\begin{array}{c}\text { Saudi Organizational Competency } \\
\text { Status } \\
\end{array}$ \\
\hline $\begin{array}{l}\text { Shaping vision for } \\
\text { six-sigma (the } \\
\text { building blocks) }\end{array}$ & $\begin{array}{l}\text {-Company was successful with TQM } \\
\text { and other quality programs } \\
\text {-Six sigma is selected as a strategic } \\
\text { choice } \\
\text {-Leadership committed to six sigma } \\
\text {-Structured leadership with a defined } \\
\text { hierarchy of decision making based } \\
\text { on fact } \\
\text {-Experience with change } \\
\text { management }\end{array}$ & $\begin{array}{l}\text {-Marginal success of TQM and other } \\
\text { quality programs, except food } \\
\text { industry (Asamadi, 2012) } \\
\text {-Six sigma is being tried as a pilot } \\
\text { project } \\
\text {-Leadership is not committed to six } \\
\text { sigma } \\
\text { Top down leadership structure } \\
\text {-Limited experience with change } \\
\text { mgt. }\end{array}$ \\
\hline $\begin{array}{l}\text { Design issues (to } \\
\text { make six-sigma } \\
\text { operational) }\end{array}$ & $\begin{array}{l}\text {-Integrated supply chains with } \\
\text { checks and balances to guarantee } \\
\text { quality } \\
\text {-Executive decisions on quality are } \\
\text { based on consensus of cross section } \\
\text { of process leaders -Decisions are } \\
\text { communicated to employees through } \\
\text { internal marketing } \\
\text {-Employee incentives are team based } \\
\text { and results oriented. }\end{array}$ & $\begin{array}{l}\text {-Supply chains are not integrated, } \\
\text { propensity to buy from ISO certified } \\
\text { suppliers } \\
\text {-Quality decisions are handed down } \\
\text { to employees by top management } \\
\text {-Internal marketing efforts are at a } \\
\text { rudimentary level } \\
\text {-There is no established incentive } \\
\text { program, depends on the pleasure of } \\
\text { top management }\end{array}$ \\
\hline
\end{tabular}




\begin{tabular}{|c|c|c|}
\hline $\begin{array}{c}\text { Strategic } \\
\text { Dimensions }\end{array}$ & $\begin{array}{c}\text { Ideal Organizational Competency } \\
\text { Identifiers }\end{array}$ & $\begin{array}{c}\text { Saudi Organizational Competency } \\
\text { Status }\end{array}$ \\
\hline $\begin{array}{l}\text { Business case for } \\
\text { each proposed } \\
\text { project (CTQ) }\end{array}$ & $\begin{array}{l}\text {-Six sigma projects are selected } \\
\text { based on CTQ, strategic fit with } \\
\text { company goals, and economic } \\
\text { justification } \\
\text {-In selecting projects complexity of } \\
\text { the change, skill set needed, its } \\
\text { impact on other projects, and supply } \\
\text { chain needs are evaluated } \\
\text {-Project team also considers any } \\
\text { potential resistance from employees } \\
\text { with a back-up contingency plan. }\end{array}$ & $\begin{array}{l}\text {-Ad Hoc six sigma projects are } \\
\text { selected based on profit potential and } \\
\text { CTQ } \\
\text {-Projects are selected by the quality } \\
\text { professionals and they have to } \\
\text { convince top management about its } \\
\text { appropriateness. } \\
\text {-There is no contingency plan if the } \\
\text { project fails, that is why only } \\
\text { projects with fail safe potential are } \\
\text { usually selected }\end{array}$ \\
\hline $\begin{array}{l}\text { Implementation } \\
\text { issues before any } \\
\text { project is launched }\end{array}$ & $\begin{array}{l}\text {-Clear guidelines for champion/team } \\
\text { leader roles and responsibilities } \\
\text { mandated by the executive suite } \\
\text {-Strict process view is used in } \\
\text { project implementation and all } \\
\text { related parties are involved } \\
\text {-Planning is done to support both } \\
\text { internal and external customers } \\
\text {-Executive suite/champion is focused } \\
\text { on creating passion for six-sigma } \\
\text { among the workforce. }\end{array}$ & $\begin{array}{l}\text {-Top management is always in } \\
\text { control, no delegation of power } \\
\text {-Process view is not used in project } \\
\text { implementation, cross functional } \\
\text { coordination is minimal } \\
\text {-Planning is not focused on internal } \\
\text { customers, only the external } \\
\text { customers and profits matter } \\
\text {-Most six sigma projects are initiated } \\
\text { by the process quality professionals, } \\
\text { management is minimally involved } \\
\text { in propagating six sigma }\end{array}$ \\
\hline Sustaining Change & $\begin{array}{l}\text {-Project successes are celebrated } \\
\text { through internal marketing } \\
\text {-Change management is taken very } \\
\text { seriously by top management } \\
\text {-Internal marketing is focused on } \\
\text { disseminating the benefits of six- } \\
\text { sigma across system. }\end{array}$ & $\begin{array}{l}\text {-Project successes are celebrated by } \\
\text { management by recognizing the } \\
\text { people involved } \\
\text {-Top management is seldom } \\
\text { involved in internal marketing } \\
\text {-Top management assumes changes } \\
\text { will take place through their } \\
\text { directives }\end{array}$ \\
\hline
\end{tabular}

The six-sigma organizational and workforce competency dimensions (Figure 1) along with their identifiers (Tables $2 \& 3$ ) came from constructs presented in the literature on six-sigma competency dimensions, their reliability, validity, and generalizability are discussed in the methodology section. The findings of this study based on comments from a cross section of quality professionals in Saudi Arabia fulfil that. Also, the use of qualitative research techniques is appropriate for gaining information inductively in such behavioral studies. This approach gave the Saudi company quality professionals the opportunity to respond openly to inquiries about their experiences in implementing six-sigma.

\section{Discussions of the Findings}

Summery result of our findings are presented in Tables $2 \& 3$. The following discussion enlarges some of the findings that are deemed critical for success of six-sigma in Saudi Arabia:

- Leadership support (Table 2) for strategy and sustainable promotion of six-sigma implementation in Saudi Arabia is lacking, rigid top down management in most Saudi family owned businesses preclude participative management or creation of horizontal organizations. After Saudi Arabia became of a member of World trade organization in 2002, there was an impetus to take quality issues more seriously and many companies adopted TQM principles. 
Among them, food industry was more successful in implementing TQM (Asamadi, et al., 2012). Top management has very limited experience with change management, and is very cautious in adopting an advanced quality management approach like six-sigma, in companies where they have six-sigma trained professionals-whether expatriate or local-it is being tried as a pilot project. It is our opinion that many companies, especially in food, drug, and industrial manufacturing Saudi Arabia has good potential for implementing six-sigma because they can hire expatriate six-sigma professionals from abroad to implement it. As these professionals are given decent salaries, they will have the motivation and the drive to live up to their contracts.

- As regards the design issues to make six-sigma operational (Table 2), one of the most important design issue is the integration of the supply chain, but the good thing in favor of Saudi Arabia is that there is a plan to improve IT infrastructure nationwide and it is supposed to trickle down to organization levels. Quality decisions should be consensus decisions of the six-sigma teams, not the way it is handed down to employees in Saudi Arabia on an ad-hoc basis. There has to be internal marketing of six-sigma principles, there is no concerted effort to popularize six-sigma in most companies where six-sigma is being tried as a pilot project. In most companies there are awards for employees, but no incentive program for six-sigma, companies should institute team based, results oriented incentive programs.

- The business case for each project (Table 2) is made based on profit potential and CTQ. In majority of cases the initiative to launch a six-sigma project is taken by top management because fear of failure deters process leaders to initiate an undertaking, if the project is selected by the quality professionals then they need to convince top management about its appropriateness. In the absence of any contingency plans if the project fails to deliver, only projects with fail safe potential are selected. In many of these companies, expatriate quality professionals are well trained and have the expertise to lead major six-sigma projects, if they are empowered to do so.

- Saudi six-sigma adopters need to take implementation issues (Table 2) more seriously. Adoption of process view, determination of process boundaries, and cross-functional coordination are essential for six-sigma success; most trained six-sigma professionals that we interviewed understand this, however, laissez-faire approach used by top management discourages process people to pledge their full commitment. Management needs to get involved, take the helm, create passion for six-sigma in the company, and monitor progress every step of the way. 


\section{TABLE 3 WORKFORCE COMPETENCY DIMENSIONS AND IDENTIFIERS}

\begin{tabular}{|c|c|c|}
\hline $\begin{array}{c}\text { Strategic } \\
\text { Dimensions }\end{array}$ & $\begin{array}{c}\text { Ideal Workforce Competency } \\
\text { Identifiers }\end{array}$ & $\begin{array}{l}\text { Saudi Workforce Competency } \\
\text { Status }\end{array}$ \\
\hline $\begin{array}{l}\text { Shaping vision for } \\
\text { six-sigma (the } \\
\text { building blocks) }\end{array}$ & $\begin{array}{l}\text {-Leadership is committed to six-sigma } \\
\text { and worker empowerment through } \\
\text { entrusting, enabling, and encouraging } \\
\text {-At least one percent of our employee } \\
\text { have the technical proficiency for six- } \\
\text { sigma } \\
\text {-Six sigma staff know that goal setting } \\
\text { (project) is based on CTQ, strategic fit } \\
\text { with company goals, and economic } \\
\text { justification }\end{array}$ & $\begin{array}{l}\text {-Leadership is not fully committed to } \\
\text { six sigma, most ad hoc projects are led } \\
\text { by professional quality staff, staff are } \\
\text { not empowered, six sigma training is } \\
\text { encouraged } \\
\text {-Most six sigma trained staff are } \\
\text { expatriate workers, it is far less than } \\
\text { one percent of total employees } \\
\text {-Goal setting is based on immediate } \\
\text { needs }\end{array}$ \\
\hline $\begin{array}{l}\text { Design issues (to } \\
\text { make six-sigma } \\
\text { operational) }\end{array}$ & $\begin{array}{l}\text {-Decisions are communicated to } \\
\text { employees through internal marketing } \\
\text {-Employee training is not limited to a } \\
\text { belt training program but is extended } \\
\text { through proactive coaching that takes } \\
\text { a process view of activities } \\
\text {-Employee incentives are team based } \\
\text { and results oriented. }\end{array}$ & $\begin{array}{l}\text {-Decisions are communicated to } \\
\text { managerial staff personally or by } \\
\text { directives by top management } \\
\text {-Personal initiative to get trained is } \\
\text { encouraged, expatriate professionals } \\
\text { are encouraged to provide proactive } \\
\text { coaching to locals } \\
\text {-Management appreciates good } \\
\text { results, incentives depend on } \\
\text { management's pleasure }\end{array}$ \\
\hline $\begin{array}{l}\text { Business case for } \\
\text { each proposed } \\
\text { project (CTQ) }\end{array}$ & $\begin{array}{l}\text {-No project is selected before a } \\
\text { thorough study of the SIPOC map and } \\
\text { employee skill set needed } \\
\text {-Emphasis on developing team skills, } \\
\text { development of collective enthusiasm } \\
\text {-Project team also considers any } \\
\text { potential resistance from employees } \\
\text { with a back-up contingency plan }\end{array}$ & $\begin{array}{l}\text {-Ad Hoc six sigma projects are } \\
\text { selected by expatriate professionals } \\
\text { after due considerations of SIPOC and } \\
\text { skills needed with approval from } \\
\text { management } \\
\text {-Quality professionals are risk averse, } \\
\text { no project is considered without } \\
\text { potential for success } \\
\text {-There is usually a contingency plan in } \\
\text { case of project failure }\end{array}$ \\
\hline $\begin{array}{l}\text { Implementation } \\
\text { issues before any } \\
\text { project is launched }\end{array}$ & $\begin{array}{l}\text {-Process leader and team members } \\
\text { understand their roles and } \\
\text { responsibilities } \\
\text {-Teams understand what the customers } \\
\text { need, that includes both internal and } \\
\text { external customers } \\
\text {-Process teams understand the } \\
\text { relationships between key process } \\
\text { input variables (KPIV) and key } \\
\text { process output variables (KPOV) }\end{array}$ & $\begin{array}{l}\text {-Expatriate quality professionals } \\
\text { understand their roles and } \\
\text { responsibilities, commitment is } \\
\text { lacking on the part of local staff } \\
\text {-Teams understand what the customers } \\
\text { need } \\
\text {-Knowledge of sophisticated causal } \\
\text { analyses techniques is minimal among } \\
\text { the quality professionals, relationships } \\
\text { between KPIV's and KPOV's are not } \\
\text { properly evaluated }\end{array}$ \\
\hline
\end{tabular}




\begin{tabular}{|l|l|l|}
\hline $\begin{array}{c}\text { Strategic } \\
\text { Dimensions }\end{array}$ & \multicolumn{1}{|c|}{$\begin{array}{c}\text { Ideal Workforce Competency } \\
\text { Identifiers }\end{array}$} & \multicolumn{1}{c|}{$\begin{array}{c}\text { Saudi Workforce Competency } \\
\text { Status }\end{array}$} \\
\hline Sustaining Change & $\begin{array}{l}\text {-To boost employee morale project } \\
\text { successes are celebrated through } \\
\text { internal marketing } \\
\text {-Six sigma staff understands the } \\
\text { importance of cohesive } \\
\text { implementation of selected projects } \\
\text {-Management continues to support six } \\
\text { sigma by patronizing new ideas, } \\
\text { methods and procedures }\end{array}$ & $\begin{array}{l}\text {-Management rewards staff for } \\
\text { improving company bottom line, i. e., } \\
\text { profits } \\
\text {-Success is celebrated through } \\
\text { company gatherings } \\
\text {-Lack of patronization from } \\
\text { management to take risks in trying } \\
\text { new approaches } \\
\text {-Staff in general are averse to risk } \\
\text { taking }\end{array}$ \\
\hline
\end{tabular}

- $\quad$ Sustaining change (Table 2) through change management is important for six-sigma success and for future projects. Although top management celebrates success by recognizing, and rewarding people involved with monetary incentives, it is done on a case by case basis; such incentives depend on the pleasure of top management, there is no established incentive program in most of the six-sigma companies in Saudi Arabia. In order to popularize sixsigma management must focus on change management to inculcate a six-sigma culture, establish a formal reward system to celebrate success, and most importantly use internal marketing to achieve employee buy-in; also, motivate expatriate six-sigma professionals to engage in proactive coaching to train the local employees.

- From workforce competency perspective (Table 3) most six sigma adopters are using it as a pilot project, based on immediate need six-sigma projects are planned, and most of these projects are led by expatriate six-sigma professionals. In our investigations we did not see any concerted effort on the part of management to adopt six-sigma as a strategic choice for longterm quality development. Although goal setting is based on CTQ issues, but projects are selected only if they promise immediate benefits to the company or there are other compulsive reasons such as fulfilling a regulatory requirement or to counter a move by a competitor.

- In a rigid top-down approach, executive decisions are communicated to managerial staff personally or by directives from top management, the executive suite in most companies either do not understand the benefits of internal marketing, or feel the approach is not culturally suitable for Saudi Arabia. There is no organized company sponsored six-sigma training programs, but personal initiative to get trained is encouraged, and expatriate sixsigma professionals are encouraged to provide proactive coaching to the locals. Top management appreciates six-sigma project initiatives, however, the burden of convincing about the benefits of the project rests on the employee (s) taking the initiative.

- Business case for each six-sigma project (Table 3) is made mostly by expatriate professionals after due considerations for SIPOC and skill set needed with approval from top management. Most of these professionals are risk averse and know that the burden of delivery rests on them, therefore, only projects with high potential for success are selected. Also, there is usually a contingency plan in case the project fails.

- Expatriate quality professionals understand their roles and responsibilities in implementing a six-sigma (Table 3) project, but convincing the local staff is the hardest challenge they face. Since most of these professionals shoulder the responsibility of success of the selected project, many-a-times they are compelled to work extra as mentor and coach to the local employees. Most six-sigma teams led by expatriate professionals understand the customer needs, however, application of sophisticated analysis techniques to relate KPIV's (Key Process Input Variables) to the KPOV's (Key Process Output Variables) is minimal. Many of 
the six-sigma professionals we talked to understand the causal techniques to relate KPIV's to the KPOV's, but the problem is scarcity of reliable data, many companies simply do not have the data Warehouse from where SIPOC data can be drawn.

- In terms of sustaining change (Table 3) staff is averse to risk taking and there is no deeprooted culture of continuous improvement. Management needs to support six-sigma by patronizing new ideas, methods and procedures, but above all, support risk taking by removing fear among the employees.

\section{CONCLUSION}

Published literature suggests that six-sigma implementation requires certain organizational and workforce competencies. We have suggested a framework for determining those competencies in the context of a developing economy like Saudi Arabia. As adoption of six-sigma quality program continues to gain momentum globally, as a member of the World Trade Organization (WTO) Saudi Arabia also needs to take quality seriously to remain competitive. Evidence from our qualitative study suggests that many companies in food, consumer goods, health care, and energy industries have either adopted sixsigma or are considering its adoption. Discussion of our finding in the previous section highlight that leadership in most companies where six-sigma is being implemented have not taken control of the initiative, it is being implemented by six-sigma professionals who are obliged to initiate only fail-safe projects. Majority of these six-sigma professionals are expatriate workers who are risk averse and they carry the burden of convincing top management for any six-sigma initiative. Most companies in Saudi Arabia are family owned and have a rigid hierarchical administrative structure, move towards shared governance has been slow but there is evidence that it is happening in some companies.

Although six-sigma has not become a pervasive quality management approach in Saudi Arabia, most Saudi companies are well versed in TQM techniques (Asamadi et al., 2012; Muhareb \& Graham-Jones, 2014). Asamadi et al. (2012) reports out of 100 Saudi Companies they have studied 32 percent are experimenting with six-sigma. Given the Saudi Government's Vision 2030-an initiative for economic development thru improvement of the private sector; availability of well-trained expatriate quality professionals; Saudi managements proclivity for immediate results; six-sigma has potential for widespread adoption in Saudi Arabia. Another advantage Saudi Companies have is the availability of strong IT infrastructure within the country and the government's effort to improve it continuously.

However, for successful implementation Saudi Management should assess their competencies. If sixsigma is adopted, management needs to form six-sigma teams both at the company level and at the process level, there needs to be a six-sigma champion who will work as the liaison between the process teams and the executive team. The current ad-hoc rewards system based on individual performance should be replaced with reward system based on team performance. The executive suite needs to get involved in design, management, and control of six-sigma projects; create the passion for six-sigma by using internal marketing within the company. Management needs to recognize comprehensive on-going training as an essential part of six-sigma; in addition, proactive coaching should become a part of the continuous improvement culture. From design for six-sigma perspective management needs to look at SIPOC map (supply-input-process-output-customer) or a value-stream map for each six-sigma project.

We recognize the limitations of this study, there is need for a more expanded study that can validate the findings of this study with quantitative estimates. However, this study has recognized the strategic competency dimensions for launching six-sigma in Saudi Arabia. 


\section{REFERENCES}

Alotaibi, F., Yusoff, R. Z., \& Islam, R. (2013). Assessing the impact of total quality management practices and quality culture with competitiveness of Saudi contractors. American Journal of Applied Sciences, 10, 638-645

Asamadi, M., Lehaney, B., \& Khan, Z. (2012). Implementing six-sigma in Saudi Arabia: An empirical study on the Fortune 100 firms. Total Quality Management, 23(3), 263-276.

Antony, J., \& Banuelas, R. (2001). A strategy for survival. Manufacturing Engineer, 80(3), 119 -121.

Azham, M. A., \& Hamidah, Y. (2011). Quality in qualitative studies: The case of validity, reliability and generalizability. Issues in Social and Environmental Accounting, 5(1-2), 25-64.

Banuelas, R., \& Antony, J. (2002). Critical success factors for the successful implementation of six sigma projects in organizations. The TQM Magazine, 14(2), 92-99.

Cohen, W., \& Levinthal, D. (1990). Absorptive capacity: A new perspective on learning and innovation. Administrative Science Quarterly, 35, 128-152.

Davis, T. R. V. (2001). Integrating internal marketing with participative management. Management Decision, 39(2), 121-133.

Davison, L., \& Al-Shaghana, K., (2007). The link between six-sigma and quality culture - An empirical study. Total Quality Management, 18(3), 249-265.

De Mast, J. (2007). Integrating the many facets of six sigma. Quality Engineering, 19, 353-361.

Easton, G. S., \& Rosenzweig, E. D. (2012). The role of experience in six-sigma project success: An empirical analysis of improvement projects. Journal of Operations Management, 30(7 \& 8), 481493.

Escrig-Tena, A. B., \& Bou-Llusar, J. C. (2005). A model for evaluating organizational competencies: An application in the context of a quality management initiative. Decision Sciences, 36(2), 221-258.

Formby, S. K., \& Dave, D. S. (2016). Organizational maturity significantly enhances six-sigma implementation success. Journal of Supply Chain Management, 13(1), 7-19.

Gutierrez, L. J., Bustinza, O. F., \& Barreles, V. (2012). Six sigma, absorptive capacity and organizational learning orientation." International Journal of Production Research, 50(3), 661-675.

Gabor, A. (2001). Management: Ford embraces six-sigma. The New York Times.

Golafshani, N. (2003). Understanding reliability and validity in qualitative research. The Qualitative Report, 8(4), 597-607.

Huq, Z. (1995). A TQM evaluation framework for hospitals: Observations from a study. International Journal of Quality and Reliability Management, 13(6), 59-76.

Huq, Z., \& Martin, T. N. (2001). Workforce cultural factors in TQM/CQI implementation in hospitals. Quality Management in Health Care, 9(2), 43-57.

Huq, Z. (2006). Six-sigma implementation through competency based perspective (CBP). Journal of Change Management, 6(3), 277-289.

Huq, Z. (2017). A competency model for assessing six-sigma implementation readiness. American Journal of Management. 17(5), 10-23.

Jayaraman, K., Kee, T. L., \& Soh, K. L. (2012). The perceptions and perspectives of Lean Six Sigma (LSS) practitioners: An empirical study in Malaysia. The TQM Journal, 24(5), 433-446.

Jones, E. C., Parast, M. M., \& Adams, S. G. (2010). A framework for effective six sigma implementation. Total Quality Management, 21(4), 415-424.

Lewis, J., \& Ritchie, J. (eds.) (2003). Qualitative research practice - A guide for social science students and researchers. London: Sage Publication.

Linderman, K. W., Schroeder, R. G., Zaheer, S., \& Choo, A. (2003). Six sigma: A goal theoretic perspective. Journal of Operations Management, 21, 193-203.

Linderman, K. W., Schroeder, R. G., \& Choo, A. (2006). Six sigma: The role of goals in improvement teams. Journal of Operations Management, 24, 779-790. 
Moosa, K., \& Ali, S. (2010). Critical analysis of six sigma implementation. Total Quality Management, 21(7), 745-759.

Motwani, J., Kumar, A., \& Antony, J. (2004). A business process change framework for examining the implementation of six-sigma: A case study of Dow Chemicals. The TQM Magazine, 16(4), 273285.

Muhareb, T. M. \& Graham-Jones, J. (2014). Using lean six-sigma in the improvement of service quality at aviation industry: case study at the departure area in KKIA (King Khaled International Airport). International Journal of Social, Management, Economics and Business Engineering, 8(1), 145-151

Naser Abdulrahman Alsaleh, (2007). Application of quality tools by the Saudi food industry. The TQM Magazine, 19(2), 150-161.

Najeh, R. I., \& Kara-Zaitri, C. (2007). A comparative study of critical quality factors in Malaysia, Palestine, Saudi Arabia, Kuwait and Libya. Total Quality Management, 18(1-2), 189-199.

Pande, P. S., \& Neuman, R. P. (2000). The six sigma way: How GE, Motorola, and other top companies are honing their performance. New York: McGraw Hill.

Pfeifer, T., Reissinger, W., \& Canales, C. (2004). Integrating six-sigma with quality management systems. The TQM Magazine, 16(4), 241-253.

Schroeder, R. G., Linderman, K., Liedtke, C., \& Choo, A. S. (2008). Six sigma: Definition and underlying theory. Journal of Operations Management, 26(4), 536-554.

Shah, R., Chandrasekaran, A., \& Linderman, K. (2008). In pursuit of implementation patterns: The context of lean and six sigma. International Journal of Production Research, 46(23), 6679-6699.

Stenbacka, C. (2001). Qualitative research requires quality concepts of its own. Management Decision, $39(7), 551-555$.

Williamson, O. E. (1999). Strategy research: governance and competence perspectives. Strategic Management Journal, 20, 1087-1108. 